\title{
Role of Entrepreneurial Activities to Accelerate Socio-Economic Development: A Study on Small Scale Shoe Industry at Bhairab in Bangladesh
}

\author{
Sara Tasneem* \\ Department of Entrepreneurship Economics, Dhaka School of Economics \\ (A Constituent Institution of the University of Dhaka) \\ Email Id: saraeconodu2006@gmail.com
}

\begin{abstract}
Bangladesh has been able to achieve socio-economic development during the last few decades. Industrialization is one of the driving forces of development process. Entrepreneurial activities play a crucial role in this regard. The present study highlights the contribution of entrepreneurs to socio-economic development. Conducting field survey and discussion with the entrepreneurs, the study reveals that remarkable socio-economic development has occurred in the study area for the efforts of entrepreneurs. The study recommends social and financial support for entrepreneurs to set up small scale industry in other regions of the country.
\end{abstract}

Key Words: Entrepreneurial Activities, Socio-Economic Development, Small Scale Shoe Industry, Bhairab (Bangladesh)

\section{PAPER/ARTICLE INFO \\ RECEIVED ON: 01/05/2020}

ACCEPTED ON: 29/06/2020

Reference to this paper should be made as follows:

Sara Tasneem (2020), "Role of Entrepreneurial Activities to Accelerate Socio-Economic Development: A Study on Small Scale Shoe Industry at Bhairab in Bangladesh", Int. J. of Trade and CommerceIIARTC, Vol. 9, No. 1, pp. 139-147 
Role of Entrepreneurial Activities to Accelerate Socio-Economic Development: A Study on Small Scale Shoe... Sara Tasneem

\section{INTRODUCTION}

Bangladesh has been able to achieve socio-economic progress in the last few decades. Since independence, Bangladesh has been trying to implement development projects to overcome socio-economic obstacles. The socio-economic indicators prove the macro-economic efforts for development. Industrialization is one of the critical drivers of the development process. Sustainable socio-economic development calls for rapid industrialization. Entrepreneurial activities play a crucial role in this regard. Entrepreneurs pave the way to socio-economic improvements as well as the enhancement of people's economic wellbeing. Entrepreneurial activities are the lifeline for industrial growth in the private sector. Long-run economic growth and development can only be achieved by promoting entrepreneurial activities. Bangladesh is trying to achieve double-digit GDP growth and sustainable development goals by 2030. Therefore, the government has taken several initiatives to encourage entrepreneurs. In this circumstance, the present study aims at focusing on the contribution of entrepreneurial activities to accelerate socio-economic development.

\section{LITERATURE REVIEW}

Rahman et al. (2011) analyze the socio-economic development of Bangladesh. The study views some socio-economic issues of the economy. The study considers the indications such as poverty, employment status, output growth, health and education services, and the expiation of business activities to measure the level of development. The study discovers the contributory role of IBBL (Islami Bank Bangladesh Limited) to improve the socio-economic condition. IBBL helps to minimize the unemployment problem by recruiting a large number of educated people each year. By providing loans to business entities, IBBL indirectly promotes employment opportunities. IBBL encourages SMEs to grow. It becomes easier to collect remittance through IBBL. IBBL provides facilities for industrial growth both in rural and urban areas. As a part of corporate social responsibility, the bank is taking initiatives to boost up the economic development of Bangladesh.

Temple (2003) assesses the development achievement of Bangladesh since its independence. Enrollment in primary education has increased remarkably. The parents become aware of girls' literacy; child and infant mortality rates, along with population growth, have shown a declining trend. Immunization coverage proves better health services. Bangladesh keeps a good record of human development. GDP (Gross Domestic Product) growth rate is increasing. The study addresses some initiatives and reforms behind the achievements. Appropriate resource allocation, foreign assistance, the participation of non-government organization, community support, liberalization policy, and prudent macroeconomic management has contributed. For further development, some other reforms such as a change in election pattern, improvement of law and order, modernized civil services, and independence of local government are required.

Sarker and Islam (2018) illustrate the significance of remittances for socio-economic progress. Remittance assists households to make current consumption and saving for the future. Households' saving creates national savings. Payment makes family members aware of children's education. It is possible to start a new business with remittance. Improvement of the standard of living takes place due to payment. The study implicates government initiatives to expand the overseas labor market.

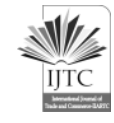


Population policy has a significant impact on the economic development of a developing country like Bangladesh. Khan (1984) deals with population growth and policy issues for the Bangladesh economy. The population is not considered as a factor in the planning process. The study analyzes the significance of the community as a variable in the development process. The rural socio-economic scenario recognizes the role of family planning programs to reduce the fertility rate.

There are heterogeneous barriers/obstacles to undermine economic development. Ahmed (2011) analyzes the walls, along with the steps taken to mitigate the issues. The study identifies the inefficient government policies; faulty administration and managerial situations impede the development process. An unethical practice at a different level of the public sector is a mentionable impediment. To eradicate the obstacles, education is necessary to raise awareness of people. The study advises strict laws to solve the unethical practices. The research also focuses on the importance of tax revenue for infrastructural improvement. The study opines that Bangladesh can reduce dependency on foreign aid by revenue generation.

Helal and Hossain (2013) assess the improvements in economic scenarios from independence to 2010. The study finds mentionable progress in economic indicators. GDP is growing at an increasing rate. The performance of the GDP growth rate is satisfactory compared to other developing countries like Bangladesh. Although the amount of cultivable is decreasing, Bangladesh has achieved dependency on the production of food grain. Poverty alleviation has taken place due to various government and non-government efforts. As poverty is counted as a major socio-economic problem, the declining trend of poverty rate is significant socio-economic progress. The study reveals the different measures taken to combat inequality. As GDP is growing, national income, saving, and investment have shown an upward trend. There is progress in social indicators also. The study suggests taking measures to control population growth rate, increase skills and abilities to the labor force, minimize environmental degradation. After all, good governance is mandatory for improvements in all aspects.

Asaduzzaaman et al. (2017) opine that industrial growth is a prime determinant of economic growth for a developing country like Bangladesh. The study sheds light on the role of industrialization on socio-economic development. Bangladesh can operate leather, textile, fertilizer, footwear, pharmaceutical industries that have a direct relationship with socio-economic issues. Bangladesh is known as an importing country. But, the trend is showing that Bangladesh becomes an exporting country. Industrial growth is promoting bilateral trade and minimizing trade deficit. The study recommends controlling environmental problems and risks resulting from industrialization.

To investigate the role of the agriculture sector in Bangladesh economy, Rahman (2017) illustrates the contribution of the industry to sustainable economic growth and development. The industry creates employment opportunities for the rural poor, makes a contribution to GDP, provides raw material to the industrial sector, and earn foreign currency through exporting agricultural product. Rural socio-economic status $\mathrm{s}$ determined by agrarian performance. The study recommends restricting the use of cultivable land for non-agricultural purposes. 
Role of Entrepreneurial Activities to Accelerate Socio-Economic Development: A Study on Small Scale Shoe... Sara Tasneem

\section{ENTREPRENEURIAL ACTIVITIES AND SOCIOECONOMIC DEVELOPMENT}

Entrepreneurial activity is the enterprising human action in pursuit of the generation of value, through the creation or expansion of economic activity, by identifying and exploiting new products, processes, or markets. Entrepreneurship is a phenomenon associated with the entrepreneurial activity (https://www.oecd.org/sdd/business-stats/39651330.pdf). Entrepreneurial activities accelerate socio-economic development (Fig.-1)

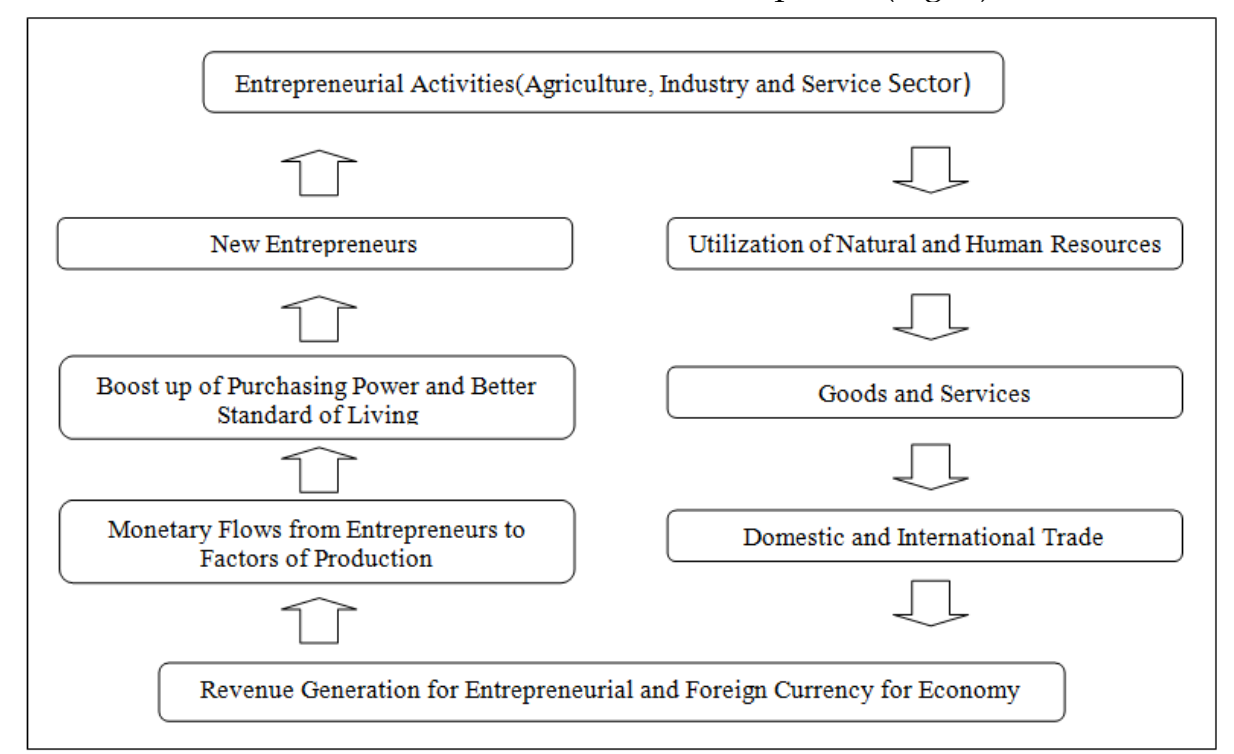

Fig.-1: Effects of Entrepreneurial Activities on Socio-economic Development

\section{4. ОвJеCTIVE}

The objective of the study is to assess the role of entrepreneurial activities to accelerate the socioeconomic development of the study area.

\section{Methodology}

The aim of the study is achieved using an exploratory mixed-method approach (Creswell, 2003; Mc Murray et al., 2004; Babbie, 1990). The study is descriptive and qualitative. Field visit at Bhairabis conducted in December 2019. Data collection was qualitative, where data was collected via semi-structured interviews with stakeholders who were directly involved in the industry. Discussion with the workers, managers, and entrepreneurs is documented. The entrepreneurs express their experience with their efforts, and the changes occurred due to shoe manufacturing. Managers share knowledge on the impacts of entrepreneurial activities on the social transformation of the area. The workers inform their improved standard of living resulting from the small scale shoe industry. The analysis is made on the documented discussion and observing the study area. Bhairab is selected as a study area as it is a famous business zone of the Dhaka Division. 


\section{SELECTION OF THE StUdy AREA}

PKSF (Polli Karma-Sahayak Foundation) introduced the PACE project in January 2015. PACE aims at enhancing livelihoods through self-employment, entrepreneurial activities, and agricultural development.

Bhairabis selected for small scale shoe industry development under the partner organization of PKSF name POPI (People's Oriented Program Implementation). The targets of the shoe industry are to increase the income of entrepreneurs and create employment opportunities. Bhairab is known as the footwear producing region. Approximately 8000 factories are operating over the last few decades. Among the enterprises, near 40 percent has been established by microentrepreneurs. Micro enterprises employ three to ten workers. The enterprises are mostly laborintensive. At the outset, the factories use inferior materials and manufacture shoes with manual labor. To improve the quality of the shoe, POPI under PACE project assists entrepreneurs to increase labor productivity. The trained entrepreneurs, along with the workers, are now capable of producing shoes by the machinery process. The entrepreneurs are now manufacturing different types of footwear, such as sandals, slippers, sports shoes, rubber shoes, and casual shoes, which can compete in local, domestic, and international markets.

\section{ANALYSIS AND FINDINGS}

\section{Economic Growth}

The entrepreneurs are adding value to GDP. The shoe is being produced with modern machinery along with the efforts of skilled labor. Labor productivity has increased due to training programs and workshops. The use of machines has accelerated the production process. The production of shoes now exhibits an increasing return to scale. Following the Cobb-Douglas production function is observed in shoe manufacturing.

$$
Y=A L^{\beta} K^{\alpha}
$$

Where, $\mathrm{Y}=$ total production of the shoe in the study area

$\mathrm{L}=$ labor used in shoemaking

$\mathrm{K}=$ capital used in shoe manufacturing (equity indicates the use of tools, machinery, and equipment)

$\alpha$ and $\beta$ are the output elasticity of capital and labor used in shoe manufacturing.

The observation and discussion with entrepreneurs reveal that show manufacturing is showing increasing returns to scale $(\alpha+\beta>1)$. Before the use of modern machinery $(\alpha+\beta)$ was less than one $(\alpha+\beta<1)$ indicating decreasing returns to scale (Fig.-2). The entrepreneurs have initiated to convert profits to scale from decreasing to the increasing stage. 
Role of Entrepreneurial Activities to Accelerate Socio-Economic Development: A Study on Small Scale Shoe... Sara Tasneem

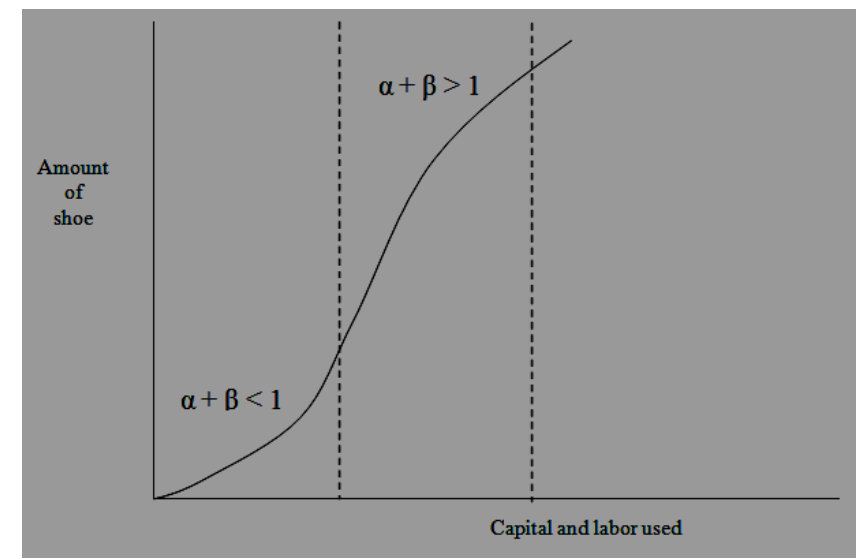

\section{Employment Creation}

Fig. 2: Production Function in the Shoe Industry

The entrepreneurs have created employment opportunities for local people. The industry has absorbed local skilled, semi-skilled unemployed people in the different manufacturing stages. Both male and female workers are employed in nine types of manufacturing operations. The operations are composed of upper cutting, pasting, sole making, fitting, finishing, screen printing, and coloring. The less educated skilled workers are engaged in the manufacturing process. Educated employees are providing managerial services. The following figure (Fig.-3) depicts the composition of the workforce.

\section{Female Participation}

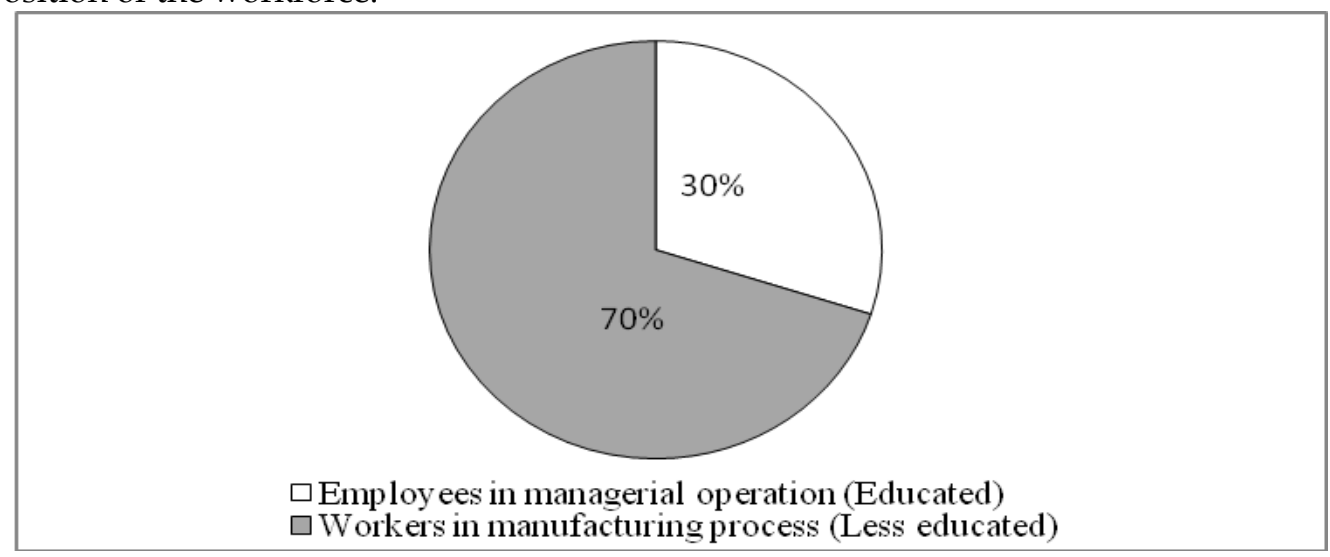

\section{Fig.-3: Composition of Workforce}

In the manufacturing process, both male and female workers are working. The numbers of female workers are approximately equal to male workers (Fig.-4) 


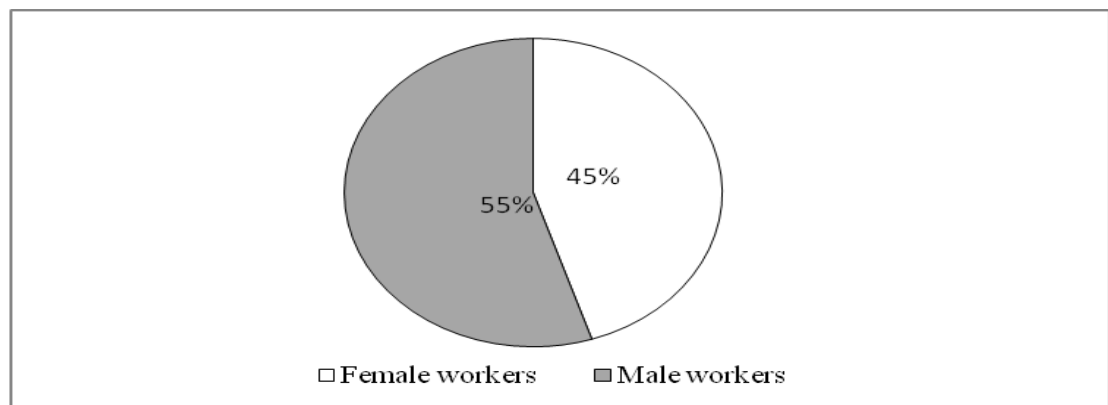

\section{Women Empowerment}

Fig. 4: Participation of Female Labor Force

Women become empowered through the motivational training of PACE projects. Women had no monetary contribution to the family before employment in the shoe industry. Now they gain selfsufficiency, decision making strength in family, and status in society.

\section{Entrepreneurship Development}

The shoe industry creates an opportunity to increase the number of entrepreneurs. In the industry, thousands of workers are working and learning how to manufacture shows. After gaining experience and completing learning, many of them (both male and female) become entrepreneurs within five to ten years.

\section{Business Expansion}

The shoe produced in the study area has an increasing demand in the domestic and overseas markets. The number of factories and showrooms are increasing. The trade center has been developed. Backward linkage industries to support shoe manufacturing are expanding their business activities. The business of intermediate products such as raw leather, rexine, paper boxes, buttons, foams, and heels are growing. The shoe based printing and color industry is emerging due to keeping pace with the change in taste and preference of the consumers. A linear relationship has been observed between the shoe industry and supporting industries (Fig.-5)

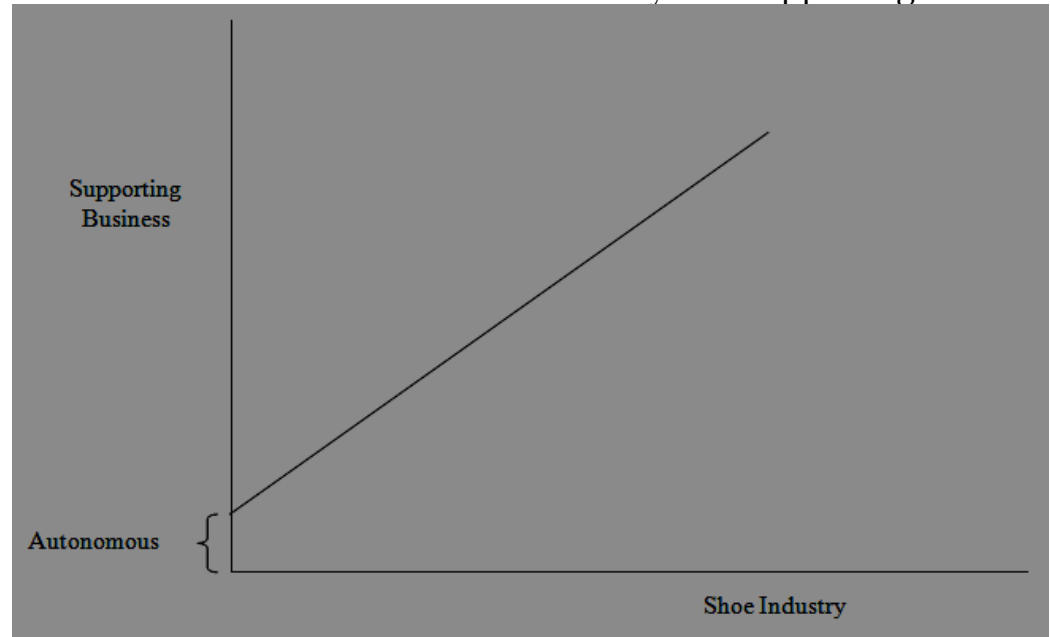

Fig.-5: Relation between Shoe Industry and Supporting Business 
Role of Entrepreneurial Activities to Accelerate Socio-Economic Development: A Study on Small Scale Shoe...

Sara Tasneem

\section{Foreign Currency}

The demand for shoes manufactured in the study area is an increasing demand in Middle-east, Asian and European countries. Bangladesh's economy earns foreign currency. The Reserve of foreign currency is a socioeconomic indicator.

\section{Education Awareness}

The operating employees in shoe manufacturing are aware of children's education. Enrollment in primary and high school is showing an upward trend.

\section{Infrastructural Development}

Infrastructural development promotes entrepreneurial activities. The entrepreneurs have taken initiatives to improve the local physical infrastructure.

\section{Consumption and Saving}

The entrepreneurs have created employment opportunities for local people. These incomegenerating activities boost up purchasing power. People satisfy basic needs, along with personal savings.

\section{Standard of Living}

The workers of the shoe industry are enjoying a better living standard than before. They are happy as children are getting an education. They are free from poverty. Health services are available. Now they are becoming financially empowered.

\section{CONCLUSION}

Socio-economic progress is essential for a country like Bangladesh. Since independence, several measures have been taken for economic growth and social development. In the late 1970s, policymakers recognize industrial development as a pre-requisite for economic growth. Economic growth promotes socio-economic development through a trickle-down effect. Along with extensive industry, small scale industries are contributing to economic growth and development. Industrialization in the private sector is the result of entrepreneurial activities. Small scale industries are more promising to ensure the survival and growth of the business. To support the entrepreneurial activities and small scale industry, the government has taken different steps and initiatives. The entrepreneurs have to face social barriers when they conduct business activities. The financial system is not always in favor of small entrepreneurs. To promote regional and national development, social and economic support to entrepreneurs is indispensable.

\section{REFERENCES}

[1]. Ahmed, K.S. (2011), Economical Development of Bangladesh - Problems \& Solutions, Arcada University of Applied Sciences, International Business, Helsinki.

[2]. Asaduzzaman; Sarkar, P; Anjum, A; and Khan, E. A. (2017), Overview of Major Industries in Bangladesh, Journal of Chemical Engineering, Vol. 30, No.1, Bangladesh Journals Online.

[3]. Babbie, E. (1990). Survey Research Methods, California, Wadsworth Inc.

[4]. Creswell, J. W. (2003), Research Design: Qualitative, Quantitative and Mixed MethodApproaches, California, Sage Publications Inc. 
Role of Entrepreneurial Activities to Accelerate Socio-Economic Development: A Study on Small Scale Shoe...

Sara Tasneem

[5]. Helal, M. and Hossain, M. A. (2013), Four Decades of Economic Development of Bangladesh: An Assessment, Journal of the Asiatic Society of Bangladesh, Vol. 58(2), Asiatic Society of Bangladesh.

[6]. Khan, M.R. (September 1984), Economic Development and Population Policy in Bangladesh, The Bangladesh Development Studies, Vol.12, No.3 Bangladesh Institute of Development Studies.

[7]. Mc Murray, A. J., Pace, W. R. and Scott, D. (2004), Research: a commonsense approach, Victoria, Thomson Social Science Press.

[8]. Rahman, M. T. (2017) Role of Agriculture in Bangladesh Economy: Uncover the Problems and Challenges, International Journal of Business and Management Invention.

[9]. Rahman, S.; Pervin, J; Jahan, S.; Nasrullah, N; and Begum, N. (September 2011), SocioEconomic Development of Bangladesh: The Role of Islami Bank Bangladesh Limited, World Journal of Social Sciences, Vol.1, No.4, Sciedu Press.

[10]. Sarker, M.M., and Islam, M.S. (2018), Impacts of International Migration on SocioEconomic Development in Bangladesh, European Review of Applied Sociology, Vol.11, No. 16, DE GRUYTER.

[11]. Temple, F.T. (26 June 2003), Seminar on Accelerating Growth \& Poverty Reduction in Bangladesh. 